\title{
Optimization of potassium fertilization/nutrition for growth, physiological development, essential oil composition and antioxidant activity of Lavandula angustifolia Mill.
}

\author{
Antonios Chrysargyris, Chryssoula Drouza, Nikos Tzortzakis*
}

Department of Agricultural Sciences, Biotechnology and Food Science, Cyprus University of Technology, Limassol, 3603, Cyprus. *Corresponding author: nikolaos.tzortzakis@cut.ac.cy

\begin{abstract}
Lavandula angustifolia (Mill.) is a medicinal plant of great importance with a variety of applications in perfume and pharmaceutical industries or landscaping, but only limited information is available about its response to potassium supplementation. This experiment was conducted in order to determine the effects of potassium (K: 275-300-325-350-375 $\mathrm{mg} \mathrm{L}^{-1}$ ) levels on the morphological and biochemical characteristics of lavender grown hydroponically. Results showed that $\mathrm{K}$ levels affected plant growth, mainly the root development while no differences were found for leaf chlorophyll content and stomatal conductance. Essential oil yield increased in the $300 \mathrm{mg} \mathrm{L}^{-1}$ in comparison to 275 or $325-375 \mathrm{mg} \mathrm{L}^{-1}$ of $\mathrm{K}$ application. The middle ranged $\mathrm{K}$ levels (300-325-350 $\mathrm{mg} \mathrm{L}^{-1}$ ) enhanced leaf content in total phenols, flavonoids and antioxidant activity (DPPH, FRAP). Lipid peroxidation content (MDA) employed as damage index, was lower in the $325 \mathrm{mg} \mathrm{L}^{-1}$ of $\mathrm{K}$ treatment. No differences were observed in antioxidant enzymes (SOD, CAT, APX) activity and $\mathrm{H}_{2} \mathrm{O}_{2}$ content among $\mathrm{K}$ applications. The main constituents of leaves essential oil (1,8-cineole, borneol, camphor, $\alpha$-terpineol, myrtenal) and mineral accumulation were affected by $\mathrm{K}$ treatments. Lavender grown in $300 \mathrm{mg} \mathrm{L}^{-1}$ of $\mathrm{K}$ was appropriate for the essential oil uses/production while the $325 \mathrm{mg} \mathrm{L}^{-1}$ of $\mathrm{K}$ were more appropriate for lavender cultivation for fresh and dry matter uses.
\end{abstract}

Keywords: Antioxidants, essential oil, Lavandula angustifolia, minerals, soilless culture 


\section{Introduction}

Common or English lavender (Lavandula angustifolia), an important evergreen perennial shrub, is used medicinally, in the perfumery, balms, salves, soaps, cosmetics and extensively used as model plant for isoprenoid biosynthesis studies (Biswas et al., 2009). Essential oil (EO) of lavender has sedative, carminative, antiseptic, anti-inflammatory, analgesic and antimicrobial (antifungal and bactericidal) properties due to the high content in terpenes (Biesiada et al., 2008). Lavender contains polyphenols, natural pigments (anthocyanins, carotenoids) and chemicals with great antioxidant role in human health; however, there is lack of knowledge in literature on the antioxidant properties of lavender (Miliauskas et al., 2004). The typical aroma of lavender is derived mainly by linalool, linalyl acetate, 1,8-cineole, o-cymene, borneol, and camphor compounds (Biswas et al., 2009). Lavender species are usually cultivated in many world regions as ornamental and medicinal plants. Moreover, lavender is native to the Mediterranean basin, in semi-arid regions, and grows in natural sites of lower parts of mountains.

Several variables are responsible for the chemical and biological diversity that medicinal and aromatic plants may have, including the growing area and crop cultural practices, microclimate, vegetative or reproductive stage as well as genetic variation (Miliauskas et al., 2004). The effect of mineral application by means of fertilizers, on lavender plant antioxidant activity as well as essential oil yield and constituents is poorly known. Due to the increasing demand for aromatic/ medicinal crop for commercial purposes, appropriate cultivation practices and mineral application are necessary. On that point, modern and precisely growing techniques such as hydroponics (growing crops without soil) may benefit crop production (Klados and Tzortzakis, 2014). The application of fertilizers and the mineral uptake/accumulation are the two most important factors that increase plant yield and productivity (Almeida et al., 2015). The essential oil production in aromatic plants may be affected positively or negatively by the form, the type and the amount of the fertilizers (Yadegari, 2015). Minerals such as nitrogen $(\mathrm{N})$, phosphorous $(\mathrm{P})$, and potassium $(\mathrm{K})$ may affect the growth and essential oil synthesis in aromatic plants and are used by plants to build many organic compounds such as amino acids, proteins, enzymes and nucleic acids. These minerals affect the function and levels of enzymes involved in the terpenoides biosynthesis (Hafsi et al., 2014). The monovalent cations, such as $\mathrm{K}$, in enzyme activation, plays a role to aid substrate binding by lowering energy barriers in the ground and/or transition states rather than being the agents of causing catalysis (Page and Di Cera, 2006). Potassium is considered a plant essential mineral that can be usually found in high concentration in tissues, in particular in the meristem and in the phloem, while Hafsi et al. (2014) reviewed that K uptake by the plant roots is accomplished by at least two distinct kinetic systems, high and low affinity $\mathrm{K}^{+}$transporters. Nurzynska-Wierdak (2013) reviewed that K deficiency may disrupt the $\mathrm{N}$ metabolism, exhibit changes in $\mathrm{N}: \mathrm{K}$ ratio and/or in the nitrogen fractions proportions as well as in the accumulation of harmful amino substances and ammonium ions in the plant. Chrysargyris et al. (2016) reported that $\mathrm{N}$ and $\mathrm{P}$ level efficiency might be related with the appropriate $\mathrm{K}$ levels in lavender plants, highlighting the needs for further study to that direction. Potassium is an important element in plant metabolism, promoting carbohydrates, fats and protein synthesis, increasing crop yield and improving fresh produce quality. Moreover, $\mathrm{K}$ is enabling plants efficacy to resist pests and diseases as well as $\mathrm{K}$ is acted as enzymes cofactor, including enzymes related to the essential oil synthesis (Cakmak, 2005; Hafsi 
et al., 2014). The application of $\mathrm{K}$ affected plant growth and essential oil yield of lemongrass (Cymbopogon flexuosus), dittany (Origanum dictamnus), basil (Ocimum basilicum) and rosemary (Rosmarinus officinalis) plants (Economakis, 1993; Puttanna et al., 2010).

Nowadays, the use of chemical fertilizers has been confined mainly to the application of $\mathrm{N}$ and $\mathrm{P}$ in soil, due to basic fertigation/applications before annual crop establishment, including vegetables, aromatic and ornamental crops -in $\mathrm{NH}_{4}-\mathrm{N}$ form for $\mathrm{N}$ - and less attention has been paid to $\mathrm{K}$, often applied as supplementary mineral, according to the crop needs. The objective of the present study was to examine the performance of $\mathrm{K}$ application on physiological and biochemical level, considering previous findings on efficacy of $\mathrm{N}$ and P levels (Chrysargyris et al., 2016) on lavender plant.

\section{Materials and Methods}

\subsection{Plant material and growth conditions}

The current study took place at the hydroponic greenhouse infrastructure of the experimental farm, at the Cyprus University of Technology, Cyprus, during two spring-summer seasons of 2013 and 2014. The effect of $\mathrm{K}$ levels into nutrient solution was examined, considering five concentration of 275,300 , 325,350 and $375 \mathrm{mg} \mathrm{L}^{-1}$ with $200 \mathrm{mg} \mathrm{L}^{-1} \mathrm{~N}$ and 50 $\mathrm{mg} \mathrm{L}^{-1} \mathrm{P}$ based on preliminary studies and/or previous reports (Chrysargyris et al., 2016). Each K treatment consisted of 6 replications (2-3 plants in each replication; 15 plants in total for each treatment). Air temperature during this period was fluctuated among 18 and $30^{\circ} \mathrm{C}$.

Lavender (L. angustifolia Mill.) plants were purchased from the Cypriot National Centre of Aromatic Plants in trays at the stage of 3-4 leaves and 4-5 $\mathrm{cm}$ height. Seedlings were transplanted into pots ( 1 per pot) with perlite ( $5 \mathrm{~L}$ per pot). Pots arranged in singles row on a density of 0.06 plants per $\mathrm{m}^{2}$.

Plants grown in an open soilless culture system, with the excess nutrient solution drained away.

A complete nutrient solution was used (Chrysargyris et al., 2016). Fertigation was applied during daytime (8 times of $1 \mathrm{~min} @ 30 \mathrm{~mL} \mathrm{~min}{ }^{-1}$ flow rate) using pressure pumps with a drip irrigation system (via emitters; one emitter plant ${ }^{-1}$ ). The target $\mathrm{pH}$ and electrical conductivity (EC) of the nutrient solution were 5.8 and $2.1 \mathrm{mS} \mathrm{cm}^{-1}$ respectively.

\subsection{Plant growth and tissue analysis}

Lavender plants were grown over one week with a complete nutrient solution application for better root establishment. Following eight weeks of plant growth with five $\mathrm{K}$-level nutrient solutions, six individual plants for each treatment were considered for detail plant growth analysis. Plant height, leaf length, root length, fresh and dry plant weight were determined for upper and root part.

\subsection{Leaf stomatal conductance and chlorophylls content}

For chlorophylls extraction, leaf tissue (six replications/treatment; each replication consisted of a pool of two plants tissue; leaf disk: $0.1 \mathrm{~g}$ ) was incubated in heat bath at $65^{\circ} \mathrm{C}$ for $30 \mathrm{~min}$, in the dark, with 10 $\mathrm{mL}$ dimethyl sulfoxide (DMSO, Sigma Aldrich, Germany). Photosynthetic leaf pigments, chlorophyll a (Chl a), chlorophyll b ( $\mathrm{Chl} \mathrm{b)} \mathrm{and} \mathrm{total} \mathrm{chlorophyll}$ (t-Chl) content were calculated as follows: $\mathrm{Chl}$ a $=0.0127 \times \mathrm{A}_{663}-0.00269 \times \mathrm{A}_{645} ; \mathrm{Chl} \mathrm{b}=0.0229$ $\times \mathrm{A}_{645}-0.00468 \times \mathrm{A}_{663} ;$ and $\mathrm{t}-\mathrm{Chl}=0.0202 \times \mathrm{A}_{645}$ $+0.00802 \times \mathrm{A}_{663}$ (Richardson et al., 2002). Stomatal conductance was measured using a $\Delta \mathrm{T}$-Porometer 
AP4 (Delta-T Devices-Cambridge, UK) according to the manufacturers Instrctions.

\subsection{Plant mineral element analysis}

Leaf (6 replications/treatment) and root (3 replications/ treatment) samples (0.2-0.3 g) were analysed for nutrient content as described in Chrysargyris et al. (2016). Determination of $\mathrm{K}, \mathrm{P}, \mathrm{Ca}, \mathrm{Mg}, \mathrm{Fe}, \mathrm{Cu}, \mathrm{Mn}, \mathrm{Zn}$, $\mathrm{Na}$, and $\mathrm{B}$ was done by inductively coupled plasma atomic emission spectrometry [ICP-AES; PSFO 2.0 (Leeman Labs INC., USA) and $\mathrm{N}$ by the Kjeldahl (BUCHI, Digest automat K-439 and Distillation Kjelflex K-360) method.

\subsection{Leaf essential oil extraction and gas chromatog- raphy/mass spectrometry analyses}

Three biological samples (pooled of three individual plants/sample) for each treatment, harvested just before flowering, and air-dried lavender leaves (in oven at $42{ }^{\circ} \mathrm{C}$ ) were chopped and approx. 15-20 g of sample were hydrodistilled for $3 \mathrm{~h}$, using Clevenger apparatus for EO extraction.

The EOs were analyzed by Gas chromatographyMass Spectrometry (GC/MS) and their constituents were determined as described previously (Chrysargyris et al., 2016).

\subsection{Leaf polyphenol extraction and analyses}

\subsubsection{Preparation of extracts}

For polyphenol extraction, six leaves samples (pooled by two individual plants/sample) for each treatment were used. The freshly cut plants $(0.5 \mathrm{~g})$ were milled with $10 \mathrm{~mL}$ methanol $(50 \% \mathrm{v} / \mathrm{v})$ and extraction was assisted with ultrasound. The samples were centrifuged for $30 \mathrm{~min}$ on $4000 \mathrm{~g}$ at $4{ }^{\circ} \mathrm{C}$
(Sigma 3-18 K, Sigma Laboratory Centrifuge, Germany). The supernatant was transferred to a $15 \mathrm{~mL}$ falcon tube, stored at $4{ }^{\circ} \mathrm{C}$ until analysis (within $48 \mathrm{~h}$ ) for evaluation of total phenolic and flavonoids content and total antioxidant activity by the DPPH and FRAP radical scavenging assay.

\subsubsection{Total phenolic content}

The total phenolic content of the methanol $(50 \% \mathrm{v} / \mathrm{v})$ extracts was determined by using Folin-Ciocalteu reagent (Merck), according to the procedure described by Tzortzakis et al. (2007). The absorbance at $755 \mathrm{~nm}$ was measured versus the prepared blank. Each measurement was repeated in triplicate and the total phenolic content was expressed as $\mu \mathrm{mol}$ of gallic acid equivalents per gram of fresh weight, through a calibration curve with gallic acid.

\subsubsection{Total flavonoid and DPPH and FRAP radical scavenging assay}

The total flavonoid content was determined according to aluminium chloride colorimetric method as modified in Chrysargyris et al. (2016). The absorbance was measured at $510 \mathrm{~nm}$. The total flavonoid concentrations are expressed as rutin equivalents ( $\mathrm{mg}$ rutin $\mathrm{g}^{-1}$ of fresh tissue). The DPPH (2,2-diphenyl-1-picrylhydrazyl) radical scavenging activity and the ferric reducing antioxidant power (FRAP) assay performed of the plant extracts, as described previously (Chrysargyris et al., 2016). Results were expressed as mg trolox $\mathrm{g}^{-1}$ of fresh weight.

\subsection{Damage index: Determination of content of $\mathrm{H}_{2} \mathrm{O}_{2}$ and lipid peroxidation}

The content of $\mathrm{H}_{2} \mathrm{O}_{2}$ was determined using the method given by Loreto and Velikova (2001). Leaf tissue of 
$0.2 \mathrm{~g}$ was ground in ice cold $0.1 \%$ trichloroacetic acid (TCA) and centrifuged at $15000 \mathrm{~g}$ for $15 \mathrm{~min}$. Then, $0.5 \mathrm{~mL}$ of the supernatant were mixed with 0.5 $\mathrm{mL}$ of $10 \mathrm{mM}$ potassium-phosphate buffer $(\mathrm{pH}=7.0)$ and $1 \mathrm{~mL}$ of $1 \mathrm{M}$ potassium iodide. $\mathrm{H}_{2} \mathrm{O}_{2}$ concentration was evaluated using a standard calibration curve plotted in the range from 5 to $1000 \mu \mathrm{M}$. The absorbance of samples and standards was read at $390 \mathrm{~nm}$ and results were expressed as $\mu \mathrm{mol} \mathrm{H}_{2} \mathrm{O}_{2} \mathrm{~g}^{-1}$ fresh weight.

Lipid peroxidation was measured in terms of malondialdeyde content (MDA) as described by Azevedo-Neto et al. (2006). Leaf tissue of $0.2 \mathrm{~g}$ was homogenized in $0.1 \%$ TCA and the extract was centrifuged at $15000 \mathrm{~g}$ for $10 \mathrm{~min}$. The reaction mixture of $0.5 \mathrm{~mL}$ extract and $1.5 \mathrm{~mL}$ of $0.5 \%$ thioarbituric acid (TBA) in $20 \%$ TCA was incubated at $95{ }^{\circ} \mathrm{C}$ for $25 \mathrm{~min}$ and then cooled on ice bath. The absorbance was determined at $532 \mathrm{~nm}$ and corrected for nonspecific absorbance at $600 \mathrm{~nm}$. MDA amount was determined using the extinction coefficient of 155 $\mathrm{mM}^{-1} \mathrm{~cm}^{-1}$. Results were expressed as nmol of MDA $\mathrm{g}^{-1}$ fresh weight.

\subsection{Activities of antioxidant enzymes}

Fresh leaf tissue was homogenized in mortar and pestle using ice cold extraction buffer containing 1 $\mathrm{mM}$ ethylenediaminetetraacetic acid (EDTA), 1\% (w/v) polyvinylpyrrolidone (PVPP), $1 \mathrm{mM}$ phenylmethylsulfonyl fluoride (PMSF) and $0.05 \%$ Triton $\mathrm{X}-100$ in $50 \mathrm{mM}$ potassium-phosphate buffer $(\mathrm{pH}=7.0)$. For APX activity extraction buffer was supplemented with $5 \mathrm{mM}$ ascorbic acid. Protein content in the enzyme extracts was determined using bovine serum albumin (BSA) as a standard (Chrysargyris et al., 2016).

Total catalase activity (CAT) (EC 1.11.1.6) and total superoxide dismutase activity (SOD) (EC 1.15.1.1) were assayed following the methods as described by Jiang and Zhang (2002). For catalase activity the reaction mixture consisted of $50 \mathrm{mM}$ potassium phosphate buffer $(\mathrm{pH}=7.0), 10 \mathrm{mM} \mathrm{H}_{2} \mathrm{O}_{2}, 10 \mu \mathrm{L}$ of extract and distilled water until final volume 1.5 $\mathrm{mL}$. Reaction started with the addition of $\mathrm{H}_{2} \mathrm{O}_{2}$, and the decrease in absorbance recorded at $240 \mathrm{~nm}$ and quantified by its extinction coefficient $\left(39.6 \mathrm{mM}^{-1}\right.$ $\mathrm{cm}^{-1}$ ). The results were expressed as CAT units $\mathrm{mg}^{-1}$ of protein ( 1 unit $=1 \mathrm{mM}$ of $\mathrm{H}_{2} \mathrm{O}_{2}$ reduction $\mathrm{min}^{-1}$ $\left.\mathrm{mg}^{-1}\right)$. SOD reaction consisted of $50 \mathrm{mM}$ potassium phosphate buffer $(\mathrm{pH}=7.5), 13 \mathrm{mM}$ methionine, 75 $\mu \mathrm{M}$ nitro blue tetrazolium (NBT), $0.1 \mathrm{mM}$ EDTA, 2 $\mu \mathrm{M}$ riboflavin and $10 \mu \mathrm{L}$ of extract. Water was added until volume reached $1.5 \mathrm{~mL}$. Reaction started with the addition of riboflavin and placing tubes with the reaction mixture below a light source of two 15 watt fluorescent lamps for $15 \mathrm{~min}$. Reaction stopped by placing the tubes in the dark. Mixtures without enzyme extract developed maximal color (control) and non-irradiated mixture used as blank. The absorbance was determined at $560 \mathrm{~nm}$ and activity was expressed as units $\mathrm{mg}^{-1}$ of protein. One unit of enzyme activity was defined as the amount of enzyme required to cause $50 \%$ inhibition of the NBT photoreduction rate.

The activity of ascorbate peroxidase (APX) (EC 1.11.1.11) was determined according to Zhu et al. (2004), by the decrease in absorbance of ascorbate at $290 \mathrm{~nm}$. The assay mixture contained $50 \mathrm{mM}$ potassium phosphate buffer $(\mathrm{pH}=7.0), 0.5 \mathrm{mM}$ ascorbic acid,0.1 mM EDTA and enzyme extract. Reaction started with the addition of $25 \mu \mathrm{L}$ of $30 \mathrm{mM} \mathrm{H}_{2} \mathrm{O}_{2}$, to a final volume of $3 \mathrm{~mL}$. The APX activity was calculated using the extinction coefficient $2.8 \mathrm{mM}^{-1} \mathrm{~cm}^{-1}$. One enzyme unit is the amount for the decomposition of $1 \mu \mathrm{mol}$ of substrate per minute. Results were expressed as units APX mg-1 of protein. 


\subsection{Statistical methods}

The whole experiment was carried out twice, with similar outcomes (EO was analysed only in the $1^{\text {st }}$ year), and therefore the 1st year experiment was further analyzed/presented. Data were statistically analysed using analysis of variance (ANOVA) by IBM SPSS v.22 for Windows, and presented as treatment mean \pm SE of six biological measurements.

Percentage values were log-transformed prior to subjecting data to ANOVA. The chemical compounds and the relationship among nutrient concentrations were determined by Linear Discriminate analysis (LDA) performed on the percentages of all identified compounds for all $\mathrm{K}$ concentrations using the SPSS program. Duncan's multiple range tests were calculated for the significant data at $\mathrm{P}<0.05$.

\section{Results}

\subsection{Growth parameters}

Table 1 presents the effect of $\mathrm{K}$ application on plant growth related variables. Leaf length and root fresh weight were significantly $(\mathrm{P}<0.05)$ increased in 325 mg L ${ }^{-1} \mathrm{~K}$ application compared with lower (275-300 $\mathrm{mg} \mathrm{L^{-1 }}$ ) or higher (350-375 $\left.\mathrm{mg} \mathrm{L}^{-1}\right) \mathrm{K}$ concentrations. The highest ratio of upper plant biomass: root was in $300 \mathrm{mg} \mathrm{L}^{-1} \mathrm{~K}$ due to the low root fresh weight of that treatment. The opposite findings were evidenced for the $325 \mathrm{mg} \mathrm{L}^{-1} \mathrm{~K}$ treatment. The $\mathrm{K}$ concentrations into nutrient solution did not affect plant height (averaged in $18.7 \mathrm{~cm}$ ), fresh and dry biomass (averaged in 15.4 and 4.4 g plant $^{-1}$ respectively). Root length was increased (up to $41 \%$ ) in $325-350 \mathrm{mg} \mathrm{L}^{-1}$ compared

Table 1. Influence of different potassium $(\mathrm{K})$ levels on lavender plant height $(\mathrm{cm})$, leaf length $(\mathrm{cm})$, biomass fresh weight (FW; g plant $\left.{ }^{-1}\right)$, biomass dry matter (DM; \%), root fresh weight (FW; g plant $\left.{ }^{-1}\right)$, root dry matter (DM; \%), biomass:root ration and root length $(\mathrm{cm})$.

\begin{tabular}{lcrrrr}
\hline K & \multicolumn{1}{c}{ K275 } & \multicolumn{1}{c}{ K300 } & \multicolumn{1}{c}{ K325 } & \multicolumn{1}{c}{ K350 } & \multicolumn{1}{c}{ K375 } \\
\hline Plant height & $18.16 \pm 1.01 \mathrm{a}$ & $18.33 \pm 0.42 \mathrm{a}$ & $20.31 \pm 0.70 \mathrm{a}$ & $17.83 \pm 0.70 \mathrm{a}$ & $19.16 \pm 1.13 \mathrm{a}$ \\
Leaf length & $5.44 \pm 0.07 \mathrm{~b}$ & $4.90 \pm 0.10 \mathrm{c}$ & $\mathbf{6 . 2 4} \pm \mathbf{0 . 1 0 a}$ & $4.88 \pm 0.09 \mathrm{c}$ & $4.99 \pm 0.17 \mathrm{c}$ \\
Biomass FW & $17.02 \pm 2.57 \mathrm{a}$ & $13.06 \pm 1.54 \mathrm{a}$ & $15.89 \pm 1.05 \mathrm{a}$ & $14.69 \pm 1.38 \mathrm{a}$ & $17.21 \pm 2.09 \mathrm{a}$ \\
Biomass DM & $28.49 \pm 1.45 \mathrm{a}$ & $30.43 \pm 0.75 \mathrm{a}$ & $28.66 \pm 0.61 \mathrm{a}$ & $29.80 \pm 0.91 \mathrm{a}$ & $27.92 \pm 0.48 \mathrm{a}$ \\
Root FW & $8.96 \pm 1.33 \mathrm{~b}$ & $3.14 \pm 0.96 \mathrm{c}$ & $\mathbf{1 9 . 0 7} \pm \mathbf{1 . 3 9 a}$ & $5.07 \pm 0.72 \mathrm{c}$ & $6.34 \pm 1.55 \mathrm{bc}$ \\
Root DM & $10.80 \pm 1.01 \mathrm{~b}$ & $\mathbf{2 7 . 2 5} \pm \mathbf{3 . 2 7} \mathbf{a}$ & $12.02 \pm 0.27 \mathrm{~b}$ & $14.94 \pm 1.19 \mathrm{~b}$ & $15.60 \pm 0.90 \mathrm{~b}$ \\
Biomass : root & $2.05 \pm 0.43 \mathrm{bc}$ & $\mathbf{5 . 3 3} \pm \mathbf{0 . 8 5 a}$ & $0.82 \pm 0.08 \mathrm{c}$ & $3.10 \pm 0.37 \mathrm{~b}$ & $3.13 \pm 0.40 \mathrm{~b}$ \\
Root length & $15.58 \pm 1.02 \mathrm{~b}$ & $17.66 \pm 1.73 \mathrm{ab}$ & $\mathbf{2 1 . 9 0} \pm \mathbf{1 . 6 8 a}$ & $\mathbf{2 0 . 0 8} \pm \mathbf{0 . 9 1 a}$ & $17.66 \pm 1.51 \mathrm{ab}$ \\
\hline
\end{tabular}

${ }^{\mathrm{Y}}$ Each value is means $\pm \mathrm{SE}(\mathrm{n}=6)$. Values in rows followed by the same letter are not significantly different, $\mathrm{P}<0.05$. K275, $\mathrm{K} 300, \mathrm{~K} 325, \mathrm{~K} 350$ and $\mathrm{K} 375$ indicate potassium concentration in $\mathrm{mg} \mathrm{L}^{-1}$, respectively.

with the $275 \mathrm{mg} \mathrm{L}^{-1} \mathrm{~K}$ application. Considering regression analysis among $\mathrm{K}$ level into nutrient solution and lavender biomass produced, it was revealed significant negative correlation $(\mathrm{Y}=-0.0001 \mathrm{x}+$ $0.0915 ; \mathrm{R}^{2}=0.70 ; \mathrm{P}=0.03$ ) as $\mathrm{K}$ levels increased from 275 to $375 \mathrm{mg} \mathrm{L}^{-1}$.

\subsection{Physiological parameters}

In the present study, neither the content of chlorophylls (Chl a, Chl b and total Chl) nor the stomatal conductivity were affected by different $\mathrm{K}$ concentrations into the nutrient solution (Table 2). 
Table 2. Influence of different $\mathrm{K}$ levels on leaf stomatal conductivity $\left(\mathrm{cm} \mathrm{s}^{-1}\right)$, chlorophylls $(\mathrm{Chl} \mathrm{a}, \mathrm{Chl} \mathrm{b}$, Total $\mathrm{Chl})$ content ( $\mathrm{mg} \mathrm{g}^{-1}$ fresh weight) and essential oil (EO) yield (\%) of lavender plants.

\begin{tabular}{llllll}
\hline K & K275 & K300 & K325 & K350 & K375 \\
\hline Stomatal conductivity & $2.13 \pm 0.78 \mathrm{a} \mathrm{Y}^{\mathrm{Y}}$ & $2.07 \pm 0.35 \mathrm{a}$ & $1.31 \pm 0.22 \mathrm{a}$ & $1.97 \pm 0.29 \mathrm{a}$ & $1.51 \pm 0.53 \mathrm{a}$ \\
Chl a & $1.07 \pm 0.05 \mathrm{a}$ & $1.11 \pm 0.04 \mathrm{a}$ & $1.10 \pm 0.19 \mathrm{a}$ & $1.08 \pm 0.04 \mathrm{a}$ & $1.11 \pm 0.06 \mathrm{a}$ \\
Chl b & $0.33 \pm 0.01 \mathrm{a}$ & $0.34 \pm 0.01 \mathrm{a}$ & $0.33 \pm 0.01 \mathrm{a}$ & $0.34 \pm 0.01 \mathrm{a}$ & $0.34 \pm 0.02 \mathrm{a}$ \\
Total Chl & $1.40 \pm 0.07 \mathrm{a}$ & $1.45 \pm 0.06 \mathrm{a}$ & $1.43 \pm 0.02 \mathrm{a}$ & $1.42 \pm 0.05 \mathrm{a}$ & $1.45 \pm 0.08 \mathrm{a}$ \\
EO & $0.93 \pm 0.05 \mathrm{~b}$ & $\mathbf{1 . 6 5} \pm \mathbf{0 . 0 3 a}$ & $0.89 \pm 0.16 \mathrm{~b}$ & $0.97 \pm 0.19 \mathrm{~b}$ & $1.00 \pm 0.21 \mathrm{~b}$ \\
\hline
\end{tabular}

${ }^{\mathrm{Y} E a c h}$ value is means $\pm \mathrm{SE}$ ( $\mathrm{n}=6$ for stomatal conductivity and Chls; $\mathrm{n}=3$ for EO). Values in rows followed by the same letter are not significantly different, $\mathrm{P}<0.05 . \mathrm{mK} 275, \mathrm{~K} 300, \mathrm{~K} 325, \mathrm{~K} 350$ and $\mathrm{K} 375$ indicate potassium concentration in mg L $\mathrm{L}^{-1}$, respectively.

Thus, the Chl a content ranged from 1.07 to $1.11 \mathrm{mg}$ g-1 fresh weight, the Chl b content ranged from 0.33 to $0.34 \mathrm{mg} \mathrm{g}^{-1}$ fresh weight and the total Chl content ranged from 1.40 to $1.45 \mathrm{mg} \mathrm{g}^{-1}$ fresh weight. Leaf stomatal conductivity ranged from 1.31 to $2.13 \mathrm{~cm} \mathrm{~s}^{-1}$ for the different $\mathrm{K}$ applications.

Intermediate potassium concentrations (300-350 mg $\left.\mathrm{L}^{-1}\right)$ affected the antioxidant activity of the lavender plants (Figure 1). Total phenols and DPPH radical scavenging activity were increased (up to $34 \%$ and $55 \%$ respectively) in 300-350 $\mathrm{mg} \mathrm{L}^{-1}$ compared with the $275 \mathrm{mg} \mathrm{L}^{-1} \mathrm{~K}$ concentration. The FRAP radical scavenging activity as well as the total flavonoids content were increased in 300,325 and $350 \mathrm{mg} \mathrm{L}^{-1} \mathrm{~K}$ applications comparing with the lowest (275 $\left.\mathrm{mg} \mathrm{L}^{-1}\right)$ and the highest ( $\left.375 \mathrm{mg} \mathrm{L}^{-1}\right) \mathrm{K}$ concentrations.

The lowest MDA content was found in $325 \mathrm{mg} \mathrm{L}^{-1}$ of $\mathrm{K}$ application while the greater one was found in $275 \mathrm{mg} \mathrm{L}^{-1}$ of $\mathrm{K}$ application (Figure 2). Neither $\mathrm{H}_{2} \mathrm{O}_{2}$ content nor the activities of antioxidant enzymes (SOD, CAT, APX) were significantly affected by $\mathrm{K}$ concentration.
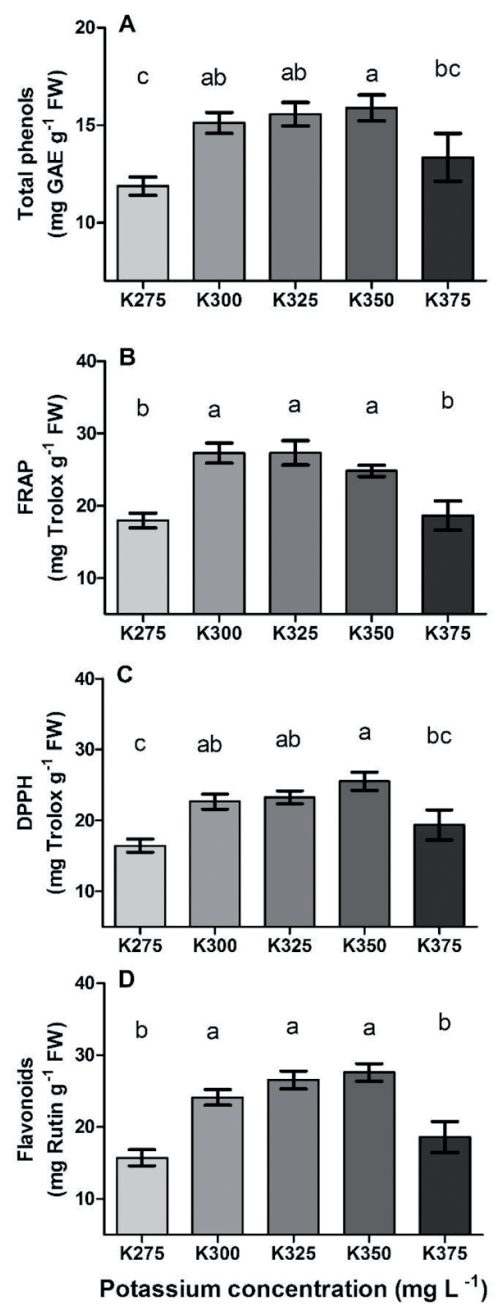

Figure 1. Effects of different potassium (K) levels on the content of total phenols and flavonoids and antioxidant activity in lavender. (A) total phenols, (B) FRAP, (C) DPPH and (D) flavonoids. Significant differences $(\mathrm{P}<0.05)$ among treatments are indicated by different letters. Error bars show SE $(n=6)$. 

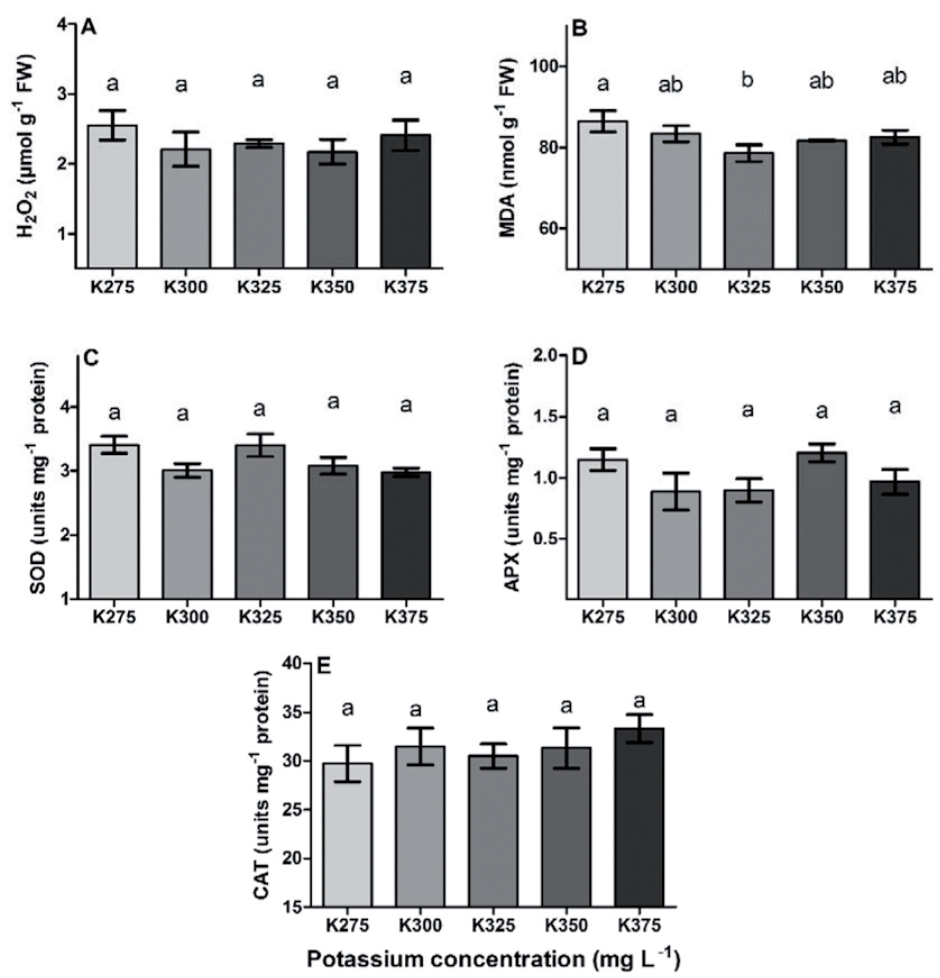

Figure 2. Effects of different potassium (K) levels on the damage index and antioxidant enzymes activities in lavender plant. (A) $\mathrm{H}_{2} \mathrm{O}_{2}$, (B) Lipid peroxidation (MDA), (C) SOD, (D) APX, and (E) CAT. Significant differences $(\mathrm{P}<0.05)$ among treatments are indicated by different letters. Error bars show $\mathrm{SE}(\mathrm{n}=6)$.

\subsection{Leaf and root nutrient content}

Increasing $\mathrm{K}$ concentration affected macronutrients and micronutrient in both leaves and roots (Tables 3 and 4). Plant tissue mineral content ranged from 17.46 to $19.19 \mathrm{~g} \mathrm{~kg}^{-1}$ for $\mathrm{N} ; 15.48$ to $18.18 \mathrm{~g} \mathrm{~kg}^{-1}$ for $\mathrm{K} ; 1.37$ to $1.68 \mathrm{~g} \mathrm{~kg}^{-1}$ for $\mathrm{P}$. The greater content for $\mathrm{N}$ (including $\mathrm{NO}_{3}$ and $\mathrm{NH}_{4}$ form, data not presented) and $\mathrm{K}$ were observed in $375 \mathrm{mg} \mathrm{L}^{-1} \mathrm{~K}$. Moreover, the greater content for $\mathrm{Ca}, \mathrm{Mg}, \mathrm{P}$ and $\mathrm{Mn}$ and the lowest $\mathrm{Al}$ (known for possible toxic effects in high concentrations) content were observed in $325 \mathrm{mg} \mathrm{L}^{-1} \mathrm{~K}$ treatment. Lower $\mathrm{K}$ concentration at $275 \mathrm{mg} \mathrm{L}^{-1}$ into nutrient solution resulted in plant higher $\mathrm{Fe}, \mathrm{Zn}$ and $\mathrm{B}$ content. The $\mathrm{Cu}$ content was not affected by the different $\mathrm{K}$ concentrations into the nutrient solution. The highest Na content was observed at $300 \mathrm{mg} \mathrm{L}^{-1}$ $\mathrm{K}$ which is lower than the optimum $\mathrm{K}$ concentration found for the above mentioned cations. Regression analysis among $\mathrm{K}$ levels into nutrient solution and lavender tissue mineral content revealed a significant positive correlation as $\mathrm{K}$ increased from 275 to 375 $\mathrm{mg} \mathrm{L}^{-1}$ for $\mathrm{N}(\mathrm{P}=0.0089)$ and $\mathrm{K}(\mathrm{P}=0.0014)$ while significant negative correlation was found for $\mathrm{Al}$ $(\mathrm{P}<0.0001), \mathrm{B}(\mathrm{P}=0.013), \mathrm{Fe}(\mathrm{P}=0.0008), \mathrm{Zn}(\mathrm{P}=$ $0.0329)$ and $\mathrm{Mg}(\mathrm{P}=0.0026)$. 
Table 3. Effects of different potassium (K) level on lavender leaf analysis (macronutrient and micronutrient)

\begin{tabular}{|c|c|c|c|c|c|}
\hline $\mathbf{K}$ & K275 & K300 & K325 & K350 & K375 \\
\hline $\mathrm{N}\left(\mathrm{g} \mathrm{kg}^{-1}\right)$ & $17.46 \pm 0.55 b^{Y}$ & $17.60 \pm 0.39 \mathrm{~b}$ & $18.62 \pm 0.43 \mathrm{ab}$ & $18.06 \pm 0.45 \mathrm{ab}$ & $19.19 \pm 0.36 \mathrm{a}$ \\
\hline $\mathrm{K}\left(\mathrm{g} \mathrm{kg}^{-1}\right)$ & $16.33 \pm 0.45 \mathrm{bc}$ & $15.48 \pm 0.36 \mathrm{c}$ & $16.44 \pm 0.54 b c$ & $16.83 \pm 0.15 b$ & $18.18 \pm 0.44 a$ \\
\hline $\mathrm{Ca}\left(\mathrm{g} \mathrm{kg}^{-1}\right)$ & $7.33 \pm 0.10 \mathrm{bc}$ & $7.57 \pm 0.27 \mathrm{ab}$ & $8.05 \pm 0.17 \mathrm{a}$ & $7.63 \pm 0.27 \mathrm{ab}$ & $6.82 \pm 0.17 \mathrm{c}$ \\
\hline$P\left(\mathrm{~g} \mathrm{~kg}^{-1}\right)$ & $1.45 \pm 0.08 \mathrm{ab}$ & $1.37 \pm 0.05 \mathrm{~b}$ & $1.68 \pm 0.08 \mathrm{a}$ & $1.55 \pm 0.09 \mathrm{ab}$ & $1.56 \pm 0.02 \mathrm{ab}$ \\
\hline $\operatorname{Mg}\left(\mathrm{g} \mathrm{kg}^{-1}\right)$ & $2.14 \pm 0.05 b c$ & $2.26 \pm 0.09 \mathrm{ab}$ & $2.18 \pm 0.04 a$ & $2.07 \pm 0.07 \mathrm{ab}$ & $1.87 \pm 0.03 \mathrm{c}$ \\
\hline $\mathrm{Na}\left(\mathrm{g} \mathrm{kg}^{-1}\right)$ & $0.66 \pm 0.07 \mathrm{ab}$ & $0.80 \pm 0.02 a$ & $0.75 \pm 0.06 \mathrm{ab}$ & $0.69 \pm 0.06 \mathrm{ab}$ & $0.58 \pm 0.01 \mathrm{~b}$ \\
\hline $\mathrm{Al}\left(\mathrm{mg} \mathrm{kg}^{-1}\right)$ & $121.83 \pm 3.52 \mathrm{a}$ & $101.50 \pm 4.88 \mathrm{~b}$ & $76.61 \pm 2.79 c$ & $90.91 \pm 6.08 b$ & $74.03 \pm 3.74 \mathrm{c}$ \\
\hline $\mathrm{Fe}\left(\mathrm{mg} \mathrm{kg}^{-1}\right)$ & $171.33 \pm 14.15 \mathrm{a}$ & $155.16 \pm 7.32 \mathrm{ab}$ & $138.91 \pm 11.30 \mathrm{abc}$ & $119.50 \pm 6.29 \mathrm{c}$ & $127.16 \pm 12.07 \mathrm{bc}$ \\
\hline $\operatorname{Mn}\left(\mathrm{mg} \mathrm{kg}{ }^{-1}\right)$ & $21.48 \pm 2.39 \mathrm{~b}$ & $26.06 \pm 2.50 \mathrm{ab}$ & $29.52 \pm 1.22 \mathrm{a}$ & $21.98 \pm 2.24 b$ & $21.71 \pm 1.70 \mathrm{~b}$ \\
\hline $\mathrm{Zn}\left(\mathrm{mg} \mathrm{kg}^{-1}\right)$ & $5.33 \pm 0.35 \mathrm{a}$ & $5.05 \pm 0.54 \mathrm{ab}$ & $3.84 \pm 0.23 b c$ & $3.43 \pm 0.54 \mathrm{c}$ & $4.29 \pm 0.22 \mathrm{abc}$ \\
\hline $\mathrm{Cu}\left(\mathbf{m g ~ k g} \mathbf{g}^{-1}\right)$ & $3.98 \pm 0.28 \mathrm{a}$ & $3.70 \pm 0.24 \mathrm{a}$ & $3.81 \pm 0.23 \mathrm{a}$ & $3.86 \pm 0.36 \mathrm{a}$ & $3.87 \pm 0.33 \mathrm{a}$ \\
\hline $\mathrm{B}\left(\mathrm{mg} \mathrm{kg}^{-1}\right)$ & $35.15 \pm 1.13 \mathrm{a}$ & $33.13 \pm 0.98 \mathrm{ab}$ & $32.61 \pm 0.76 \mathrm{ab}$ & $32.45 \pm 1.77 \mathrm{ab}$ & $30.45 \pm 1.35 \mathrm{~b}$ \\
\hline
\end{tabular}

${ }^{\mathrm{Y}}$ Each value is means $\pm \mathrm{SE}(\mathrm{n}=6)$. Values in rows followed by the same letter are not significantly different, $\mathrm{P}<0.05$. $\mathrm{K} 275, \mathrm{~K} 300, \mathrm{~K} 325, \mathrm{~K} 350$ and $\mathrm{K} 375$ indicate potassium concentration in $\mathrm{mg} \mathrm{L}^{-1}$, respectively.

Table 4. Effects of different potassium (K) level on lavender root analysis (macronutrient and micronutrient)

\begin{tabular}{|c|c|c|c|c|c|}
\hline $\mathbf{K}$ & K275 & K300 & K325 & K350 & K375 \\
\hline$N\left(\mathrm{~g} \mathrm{~kg}^{-1}\right)$ & $19.51 \pm 0.12 b^{Y}$ & $21.15 \pm 1.57 \mathrm{~b}$ & $25.83 \pm 1.55 a$ & $18.42 \pm 0.60 \mathrm{~b}$ & $19.93 \pm 0.08 b$ \\
\hline $\mathrm{K}\left(\mathrm{g} \mathrm{kg}^{-1}\right)$ & $13.02 \pm 1.20 \mathrm{~b}$ & $15.46 \pm 1.03 \mathrm{~b}$ & $22.65 \pm 0.67 \mathrm{a}$ & $13.40 \pm 0.92 \mathrm{~b}$ & $13.85 \pm 1.81 \mathrm{~b}$ \\
\hline $\mathrm{Ca}\left(\mathrm{g} \mathrm{kg}^{-1}\right)$ & $13.83 \pm 1.77 \mathrm{a}$ & $11.37 \pm 1.36 \mathrm{a}$ & $9.59 \pm 0.53 \mathrm{a}$ & $14.06 \pm 1.70 \mathrm{a}$ & $11.48 \pm 1.62 \mathrm{a}$ \\
\hline$P\left(\mathrm{~g} \mathrm{~kg}^{-1}\right)$ & $2.90 \pm 0.12 \mathrm{a}$ & $3.34 \pm 0.14 \mathrm{a}$ & $2.85 \pm 0.35 \mathrm{a}$ & $3.27 \pm 0.20 \mathrm{a}$ & $2.77 \pm 0.02 \mathrm{a}$ \\
\hline $\mathbf{M g}\left(\mathbf{g ~ k g}^{-1}\right)$ & $3.57 \pm 0.16 \mathrm{~b}$ & $3.64 \pm 0.04 \mathrm{~b}$ & $4.43 \pm 0.30 \mathrm{a}$ & $3.45 \pm 0.08 \mathrm{~b}$ & $3.45 \pm 0.02 \mathrm{~b}$ \\
\hline $\mathrm{Na}\left(\mathrm{g} \mathrm{kg}^{-1}\right)$ & $4.98 \pm 0.61 \mathrm{~b}$ & $4.97 \pm 0.34 \mathrm{~b}$ & $7.70 \pm 0.80 \mathrm{a}$ & $3.65 \pm 0.28 \mathrm{~b}$ & $3.75 \pm 0.43 b$ \\
\hline $\mathrm{Al}\left(\mathrm{mg} \mathrm{kg}^{-1}\right)$ & $191.00 \pm 30.08 \mathrm{a}$ & $134.33 \pm 30.71 \mathrm{a}$ & $151.31 \pm 22.80 \mathrm{a}$ & $224.66 \pm 61.41 \mathrm{a}$ & $162.00 \pm 33.00 \mathrm{a}$ \\
\hline $\mathrm{Fe}\left(\mathrm{mg} \mathrm{kg}^{-1}\right)$ & $487.66 \pm 47.47 \mathrm{a}$ & $337.00 \pm 43.14 \mathrm{a}$ & $323.00 \pm 31.16 \mathrm{a}$ & $467.00 \pm 97.81 \mathrm{a}$ & $390.00 \pm 73.90 \mathrm{a}$ \\
\hline $\operatorname{Mn}\left(\mathrm{mg} \mathrm{kg}^{-1}\right)$ & $120.00 \pm 7.00 \mathrm{c}$ & $121.66 \pm 15.19 \mathrm{c}$ & $144.61 \pm 17.54 \mathrm{bc}$ & $185.00 \pm 9.45 \mathrm{a}$ & $181.50 \pm 5.48 \mathrm{ab}$ \\
\hline Zn (mg kg-1) & $29.70 \pm 0.60 \mathrm{a}$ & $26.73 \pm 3.79 \mathrm{a}$ & $22.23 \pm 4.01 \mathrm{a}$ & $27.33 \pm 3.09 \mathrm{a}$ & $24.56 \pm 1.81 \mathrm{a}$ \\
\hline $\mathrm{Cu}\left(\mathrm{mg} \mathrm{kg}^{-1}\right)$ & $78.23 \pm 4.87 \mathrm{a}$ & $81.21 \pm 3.07 \mathrm{a}$ & $70.01 \pm 3.11 \mathrm{a}$ & $71.62 \pm 6.81 \mathrm{a}$ & $70.86 \pm 5.10 \mathrm{a}$ \\
\hline B $\left(\mathrm{mg} \mathrm{kg}^{-1}\right)$ & $28.26 \pm 1.67 \mathrm{~b}$ & $22.33 \pm 1.26 \mathrm{bc}$ & $36.61 \pm 4.0 .7 \mathrm{a}$ & $22.60 \pm 1.50 \mathrm{bc}$ & $18.10 \pm 0.05 \mathrm{c}$ \\
\hline
\end{tabular}

${ }^{\mathrm{Y}}$ Each value is means $\pm \mathrm{SE}(\mathrm{n}=3)$. Values in rows followed by the same letter are not significantly different, $\mathrm{P}<0.05$. $\mathrm{K} 275$, K300, K325, K350 and K375 indicate potassium concentration in $\mathrm{mg} \mathrm{L}^{-1}$, respectively.

\subsection{Essential oil yield and constituents}

Lavender EO yield significantly $(\mathrm{P}<0.05)$ increased in $300 \mathrm{mg} \mathrm{L}^{-1}$ of $\mathrm{K}$ application, while no differences on essential oil yield were found for the 275,325 , 350 and $375 \mathrm{mg} \mathrm{L}^{-1} \mathrm{~K}$ treatments (Table 2). The effects of different $\mathrm{K}$ levels on EO chemical composition are presented in Table 5.
Thirty nine components were identified in the EOs of lavender plants underwent at different treatments that represented $99.32-99.66 \%$ of the oils. It can be noticed that hydrocarbon compounds ranged from 9.01 to $10.31 \%$ while oxygenated (monoterpenes and sesquiterpenes) compounds were ranged from 85.78 to 88.40 and 1.40 to $2.78 \%$, respectively. 
Table 5. Effects of different potassium (K) level on lavender leave chemical composition (\%) of essential oils

\begin{tabular}{|c|c|c|c|c|c|c|}
\hline \multirow[b]{2}{*}{ Compound } & \multirow[b]{2}{*}{ RI } & \multicolumn{5}{|c|}{ K concentrations } \\
\hline & & K275 & K300 & K325 & K350 & K375 \\
\hline$\alpha$-Pinene & 933 & $2.05 \pm 0.11 \mathrm{a}$ & $2.11 \pm 0.08 \mathrm{a}$ & $2.10 \pm 0.02 \mathrm{a}$ & $2.04 \pm 0.09 \mathrm{a}$ & $2.28 \pm 0.18 \mathrm{a}$ \\
\hline Camphene & 948 & $0.43 \pm 0.03 \mathrm{a}$ & $0.43 \pm 0.03 \mathrm{a}$ & $0.50 \pm 0.00 \mathrm{a}$ & $0.44 \pm 0.07 \mathrm{a}$ & $0.44 \pm 0.05 \mathrm{a}$ \\
\hline Thuja-2.4 (10)- diene & 954 & $0.04 \pm 0.00 \mathrm{~b}$ & $0.04 \pm 0.00 \mathrm{~b}$ & $0.09 \pm 0.02 \mathrm{a}$ & $0.05 \pm 0.00 \mathrm{~b}$ & $0.04 \pm 0.00 \mathrm{~b}$ \\
\hline Sabinene & 973 & $0.84 \pm 0.04 \mathrm{ab}$ & $0.78 \pm 0.03 \mathrm{~b}$ & $0.98 \pm 0.03 \mathrm{a}$ & $0.82 \pm 0.01 \mathrm{~b}$ & $0.88 \pm 0.09 \mathrm{ab}$ \\
\hline$\beta$-Pinene & 977 & $3.47 \pm 0.22 \mathrm{a}$ & $3.25 \pm 0.16 \mathrm{a}$ & $3.55 \pm 0.00 \mathrm{a}$ & $3.32 \pm 0.10 \mathrm{a}$ & $3.65 \pm 0.33 \mathrm{a}$ \\
\hline$\beta$-Myrcene & 991 & $0.37 \pm 0.02 \mathrm{a}$ & $0.43 \pm 0.02 \mathrm{a}$ & $0.43 \pm 0.00 \mathrm{a}$ & $0.46 \pm 0.07 \mathrm{a}$ & $0.47 \pm 0.01 \mathrm{a}$ \\
\hline$\alpha$-Terpinene & 1017 & $0.14 \pm 0.01 \mathrm{ab}$ & $0.12 \pm 0.01 \mathrm{~b}$ & $0.20 \pm 0.02 \mathrm{a}$ & $0.12 \pm 0.02 \mathrm{ab}$ & $0.13 \pm 0.02 \mathrm{ab}$ \\
\hline o-Cymene & 1024 & $0.16 \pm 0.00 \mathrm{~b}$ & $0.14 \pm 0.00 \mathrm{bc}$ & $0.21 \pm 0.00 \mathrm{a}$ & $0.16 \pm 0.01 \mathrm{~b}$ & $0.12 \pm 0.01 \mathrm{c}$ \\
\hline Limonene & 1028 & $1.65 \pm 0.13 \mathrm{ab}$ & $1.37 \pm 0.00 \mathrm{~b}$ & $1.69 \pm 0.07 a b$ & $1.43 \pm 0.01 \mathrm{~b}$ & $1.80 \pm 0.19 \mathrm{a}$ \\
\hline 1.8-Cineole & 1031 & $59.72 \pm 1.17 \mathrm{~b}$ & $63.00 \pm 1.53 \mathrm{a}$ & $58.54 \pm 0.59 \mathrm{~b}$ & $62.95 \pm 1.45 \mathrm{a}$ & $62.22 \pm 0.17 \mathrm{ab}$ \\
\hline$\gamma$-Terpinene & 1058 & $0.31 \pm 0.01 \mathrm{ab}$ & $0.25 \pm 0.00 \mathrm{~b}$ & $0.40 \pm 0.03 \mathrm{a}$ & $0.26 \pm 0.03 \mathrm{~b}$ & $0.30 \pm 0.04 \mathrm{ab}$ \\
\hline cis-Sabinene hydrate & 1067 & $0.43 \pm 0.06 \mathrm{a}$ & $0.48 \pm 0.02 \mathrm{a}$ & $0.67 \pm 0.12 \mathrm{a}$ & $0.56 \pm 0.10 \mathrm{a}$ & $0.51 \pm 0.04 \mathrm{a}$ \\
\hline p-Mentha-2.4(8)-diene & 1089 & $0.06 \pm 0.00 \mathrm{~b}$ & $0.06 \pm 0.00 \mathrm{~b}$ & $0.12 \pm 0.01 \mathrm{a}$ & $0.07 \pm 0.01 \mathrm{~b}$ & $0.06 \pm 0.00 \mathrm{~b}$ \\
\hline Linalool & 1100 & $0.17 \pm 0.00 \mathrm{a}$ & $0.16 \pm 0.01 \mathrm{a}$ & $0.23 \pm 0.04 \mathrm{a}$ & $0.17 \pm 0.02 \mathrm{a}$ & $0.17 \pm 0.00 \mathrm{a}$ \\
\hline Fenchol & 1114 & $0.03 \pm 0.00 \mathrm{~b}$ & $0.03 \pm 0.00 \mathrm{~b}$ & $0.09 \pm 0.01 \mathrm{a}$ & $0.03 \pm 0.00 \mathrm{~b}$ & $0.04 \pm 0.00 \mathrm{~b}$ \\
\hline$\alpha$-Campholenal & 1127 & $0.26 \pm 0.00 \mathrm{~b}$ & $0.22 \pm 0.01 \mathrm{~b}$ & $0.34 \pm 0.02 \mathrm{a}$ & $0.22 \pm 0.00 \mathrm{~b}$ & $0.22 \pm 0.02 \mathrm{~b}$ \\
\hline trans-Pinocarveol & 1139 & $0.97 \pm 0.07 \mathrm{ab}$ & $1.00 \pm 0.03 \mathrm{ab}$ & $1.17 \pm 0.01 \mathrm{a}$ & $0.93 \pm 0.07 \mathrm{~b}$ & $0.92 \pm 0.07 \mathrm{~b}$ \\
\hline cis-Verbenol & 1141 & $0.05 \pm 0.03 \mathrm{~b}$ & $0.08 \pm 0.01 \mathrm{ab}$ & $0.11 \pm 0.00 \mathrm{a}$ & $0.06 \pm 0.01 \mathrm{ab}$ & $0.03 \pm 0.01 \mathrm{~b}$ \\
\hline Camphor & 1145 & $5.73 \pm 0.94 \mathrm{~b}$ & $5.77 \pm 0.30 \mathrm{~b}$ & $8.02 \pm 0.11 \mathrm{a}$ & $8.18 \pm 0.45 \mathrm{a}$ & $5.55 \pm 0.07 \mathrm{~b}$ \\
\hline Pinocarvone & 1163 & $0.90 \pm 0.00 \mathrm{~b}$ & $0.83 \pm 0.01 \mathrm{~b}$ & $1.01 \pm 0.04 \mathrm{a}$ & $0.83 \pm 0.00 \mathrm{~b}$ & $0.83 \pm 0.01 \mathrm{~b}$ \\
\hline Borneol & 1166 & $11.85 \pm 0.61 \mathrm{a}$ & $11.02 \pm 0.95 \mathrm{a}$ & $9.09 \pm 0.37 \mathrm{~b}$ & $8.56 \pm 0.05 \mathrm{~b}$ & $11.06 \pm 0.14 \mathrm{a}$ \\
\hline Terpinen-4-ol & 1178 & $0.61 \pm 0.02 \mathrm{a}$ & $0.65 \pm 0.01 \mathrm{a}$ & $0.66 \pm 0.02 \mathrm{a}$ & $0.53 \pm 0.01 \mathrm{~b}$ & $0.61 \pm 0.01 \mathrm{a}$ \\
\hline p-Cymen-8-ol & 1185 & $0.11 \pm 0.01 \mathrm{a}$ & $0.14 \pm 0.01 \mathrm{a}$ & $0.11 \pm 0.00 \mathrm{a}$ & $0.10 \pm 0.02 \mathrm{a}$ & $0.11 \pm 0.03 \mathrm{a}$ \\
\hline Cryptone & 1187 & $0.27 \pm 0.01 \mathrm{a}$ & $0.38 \pm 0.00 \mathrm{a}$ & $0.22 \pm 0.02 \mathrm{a}$ & $0.23 \pm 0.05 \mathrm{a}$ & $0.29 \pm 0.09 \mathrm{a}$ \\
\hline$\alpha$-Terpineol & 1191 & $2.11 \pm 0.13 \mathrm{a}$ & $2.12 \pm 0.18 \mathrm{a}$ & $2.16 \pm 0.02 \mathrm{a}$ & $2.02 \pm 0.05 \mathrm{a}$ & $2.31 \pm 0.20 \mathrm{a}$ \\
\hline Myrtenal & 1197 & $2.15 \pm 0.09 \mathrm{ab}$ & $1.86 \pm 0.09 \mathrm{c}$ & $2.38 \pm 0.03 \mathrm{a}$ & $1.90 \pm 0.08$ bc & $1.88 \pm 0.05 \mathrm{c}$ \\
\hline Verbenone & 1211 & $0.05 \pm 0.01 \mathrm{a}$ & $0.11 \pm 0.00 \mathrm{a}$ & $0.05 \pm 0.02 \mathrm{a}$ & $0.06 \pm 0.02 \mathrm{a}$ & $0.07 \pm 0.05 \mathrm{a}$ \\
\hline trans-Carveol & 1219 & $0.21 \pm 0.03 \mathrm{a}$ & $0.23 \pm 0.02 \mathrm{a}$ & $0.26 \pm 0.01 \mathrm{a}$ & $0.18 \pm 0.04 \mathrm{a}$ & $0.17 \pm 0.05 \mathrm{a}$ \\
\hline Bornyl formate & 1229 & $0.13 \pm 0.03 \mathrm{a}$ & $0.12 \pm 0.00 \mathrm{a}$ & $0.11 \pm 0.01 \mathrm{a}$ & $0.05 \pm 0.00 \mathrm{~b}$ & $0.10 \pm 0.01 \mathrm{a}$ \\
\hline Cumin aldehyde & 1241 & $0.26 \pm 0.01 \mathrm{ab}$ & $0.21 \pm 0.00 \mathrm{bc}$ & $0.28 \pm 0.02 \mathrm{a}$ & $0.20 \pm 0.00 \mathrm{c}$ & $0.20 \pm 0.00 \mathrm{c}$ \\
\hline Carvone & 1244 & $0.23 \pm 0.00 \mathrm{abc}$ & $0.24 \pm 0.00 \mathrm{ab}$ & $0.27 \pm 0.05 \mathrm{a}$ & $0.22 \pm 0.01 \mathrm{bc}$ & $0.20 \pm 0.02 \mathrm{c}$ \\
\hline p-Cymen-7-ol & 1291 & $0.14 \pm 0.01 \mathrm{ab}$ & $0.12 \pm 0.01 \mathrm{ab}$ & $0.17 \pm 0.00 \mathrm{a}$ & $0.10 \pm 0.03 a b$ & $0.08 \pm 0.03 \mathrm{~b}$ \\
\hline p-Mentha-1.4-dien-7-ol & 1329 & $0.11 \pm 0.00 \mathrm{a}$ & $0.08 \pm 0.01 \mathrm{a}$ & $0.11 \pm 0.00 \mathrm{a}$ & $0.07 \pm 0.02 \mathrm{a}$ & $0.05 \pm 0.02 \mathrm{a}$ \\
\hline Coumarin & 1443 & $0.05 \pm 0.00 \mathrm{a}$ & $0.07 \pm 0.01 \mathrm{a}$ & $0.08 \pm 0.02 \mathrm{a}$ & $0.05 \pm 0.02 \mathrm{a}$ & $0.07 \pm 0.02 \mathrm{a}$ \\
\hline Caryophyllene oxide & 1587 & $0.52 \pm 0.03 \mathrm{a}$ & $0.26 \pm 0.02 \mathrm{~b}$ & $0.48 \pm 0.02 \mathrm{a}$ & $0.32 \pm 0.02 \mathrm{~b}$ & $0.27 \pm 0.00 \mathrm{~b}$ \\
\hline tau-Cadinol & 1642 & $0.64 \pm 0.03 \mathrm{a}$ & $0.33 \pm 0.04 \mathrm{c}$ & $0.56 \pm 0.03 \mathrm{ab}$ & $0.44 \pm 0.07 \mathrm{bc}$ & $0.35 \pm 0.01 \mathrm{c}$ \\
\hline Bisabolol oxide II & 1656 & $0.30 \pm 0.03 \mathrm{a}$ & $0.14 \pm 0.00 \mathrm{~b}$ & $0.27 \pm 0.01 \mathrm{a}$ & $0.15 \pm 0.03 \mathrm{~b}$ & $0.11 \pm 0.02 \mathrm{~b}$ \\
\hline$\alpha$-Bisabolol & 1685 & $1.32 \pm 0.08 \mathrm{a}$ & $0.66 \pm 0.06 \mathrm{~b}$ & $1.08 \pm 0.04 \mathrm{ab}$ & $0.97 \pm 0.18$ ab & $0.78 \pm 0.03 \mathrm{~b}$ \\
\hline Muurol-5-en-4-one & 1689 & $0.47 \pm 0.03 \mathrm{a}$ & $0.23 \pm 0.02 \mathrm{c}$ & $0.39 \pm 0.02 \mathrm{ab}$ & $0.26 \pm 0.06 \mathrm{bc}$ & $0.20 \pm 0.03 \mathrm{c}$ \\
\hline Monoterpenes hydrocarbons & & $9.54 \pm 0.52 \mathrm{a}$ & $9.01 \pm 0.28 \mathrm{a}$ & $10.31 \pm 0.03 \mathrm{a}$ & $9.20 \pm 0.25 \mathrm{a}$ & $10.19 \pm 0.95 \mathrm{a}$ \\
\hline Sesquiterpenes hydrocarbons & & 0.00 & 0.00 & 0.00 & 0.00 & 0.00 \\
\hline Oxygenated monoterpenes & & $86.10 \pm 0.80 \mathrm{~b}$ & $88.40 \pm 0.09 \mathrm{a}$ & $85.78 \pm 0.31 \mathrm{~b}$ & $87.93 \pm 0.39$ a & $87.27 \pm 0.67 \mathrm{ab}$ \\
\hline Oxygenated sesquiterpenes & & $2.78 \pm 0.16 \mathrm{a}$ & $1.40 \pm 0.13 \mathrm{c}$ & $2.41 \pm 0.11 \mathrm{ab}$ & $1.89 \pm 0.32 \mathrm{bc}$ & $1.53 \pm 0.07 \mathrm{c}$ \\
\hline Others & & $0.92 \pm 0.07 \mathrm{a}$ & $0.80 \pm 0.01 \mathrm{a}$ & $0.82 \pm 0.07 \mathrm{a}$ & $0.60 \pm 0.13 \mathrm{a}$ & $0.66 \pm 0.05 \mathrm{a}$ \\
\hline Total & & $99.34 \pm 0.4 \mathrm{a}$ & $99.63 \pm 0.04 \mathrm{a}$ & $99.32 \pm 0.17$ a & $99.66 \pm 0.14 \mathrm{a}$ & $99.51 \pm 0.07 \mathrm{a}$ \\
\hline
\end{tabular}

Each value is means $\pm \mathrm{SE}(\mathrm{n}=3)$. Values in rows followed by the same letter are not significantly different, $\mathrm{P}<0.05$. $\mathrm{K} 275$, K300, K325, K350 and K375 indicate potassium concentration in $\mathrm{mg} \mathrm{L}^{-1}$, respectively. 
The major components were 1,8-cineole (alcohol; 58.54-63.00\%), borneol (alcohol; 8.56-11.85\%), camphor (ketone; 5.55-8.18\%), $\beta$-pinene (monoterpene hydrocarbon; 3.25-3.65\%), $\alpha$-terpineol (alcohol; 2.02-2.31\%), myrtenal (aldehyde; 1.86-2.38\%), $\alpha$-pinene (monoterpene hydrocarbon; 2.04-2.28\%), limonene (monoterpene hydrocarbon; 1.37-1.80\%), $\alpha$-bisabolol (alcohol; 0.66-1.32\%) and trans-pinocarveol (alcohol; 0.92-1.17\%). Other components were present in amounts less than $1 \%$ in most treatments.

Examining the $\mathrm{K}$ effects on oil constituents, 1,8-cineole reached to its maximal percentage $(63.00 \%)$ as a

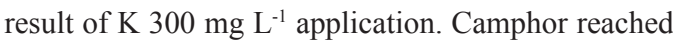
the greatest $(8.18 \%)$ value at $350 \mathrm{mg} \mathrm{L}^{-1} \mathrm{~K}$ and the lowest (5.55\%) value at $375 \mathrm{mg} \mathrm{L}^{-1} \mathrm{~K}$. Myrtenal greatest percentage was reached at $325 \mathrm{mg} \mathrm{L}^{-1} \mathrm{~K}$, while the lowest value was obtained at the $300 \mathrm{mg} \mathrm{L}^{-1} \mathrm{~K}$. Borneol content was increased in 275, 300 and $375 \mathrm{mg}$ $\mathrm{L}^{-1} \mathrm{~K}$ applications. Other components which differed significantly among $\mathrm{K}$ levels were trans-pinocarveol (0.92-1.17\%), limonene (1.37-1.80\%) and $\alpha$-bisabolol (0.66-1.32\%). No differences were found in $\alpha$-terpineol (averaged in 2.14\%), $\beta$-pinene (averaged in 3.45) and $\alpha$-pinene (averaged in 2.11\%). The linear discriminate analysis was used in order to identify possible relationships between EO constituents and $\mathrm{K}$ concentration (Figure 3 ). The LDA, performed on average contents of all compounds for each $\mathrm{K}$ concentration, showed that the first two principal axes represented $85.2 \%$ of the total variation, with 10 EO compounds were identified as having effects. The first axis $(65.5 \%$ of the total variation) was mainly correlated with $\alpha$-terpinene, cis-sabinenehydrate and o-cymene. The second axis represented $19.5 \%$ of the total variation, with the $\alpha$-pinene, limonene, camphene, $\beta$-pinene, thuja-2,4(10)-diene, $\beta$-myrcene and sabinene consisting the main compounds contributing to its definition.

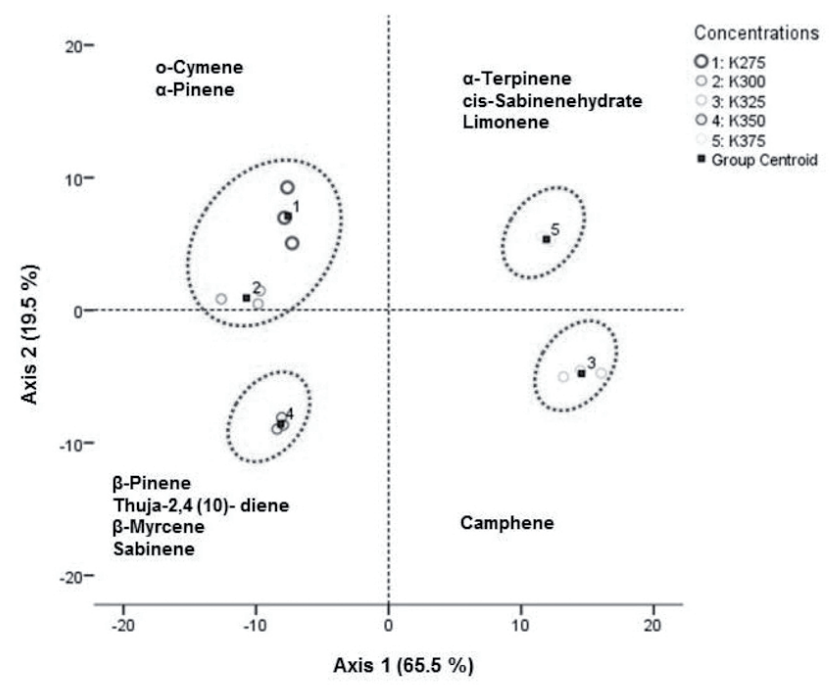

Figure 3. Linear discriminant analysis (LDA) for the lavender essential oil compounds under different potassium (K) levels. Projection of the average contents of the essential oil compounds onto the first two principal axes ( + and - indicate positive and negative correlations with axes, respectively). Coding numbers referred to K concentrations. 
According to the LDA, four concentration groups in relation to the nutrient solution could be distinguished situated at the periphery of the plot. The first group represented by concentration $375 \mathrm{mg} \mathrm{L}^{-1} \mathrm{~K}$, situated at the positive side of axis 1 and 2. The second group represented by $325 \mathrm{mg} \mathrm{L}^{-1} \mathrm{~K}$, situated at the positive side of axis 1 and at the negative side of axis 2 . The third group represented by $350 \mathrm{mg} \mathrm{L}^{-1} \mathrm{~K}$, situated at the negative sites of both axis 1 and 2 . The fourth group represented by $275 \mathrm{mg} \mathrm{L}^{-1} \mathrm{~K}$ and $300 \mathrm{mg} \mathrm{L}^{-1}$ $\mathrm{K}$, situated at the negative side of axis 1 and the positive side of axis 2 .

\section{Discussion}

The aim of this study was to optimize the $\mathrm{K}$ fertigation/nutrition in different levels for the L. angustifolia growth, physiological development, mineral content, antioxidant activity and essential oil composition. Previous experimentation on effects of $\mathrm{N}$ and $\mathrm{P}$ levels on lavender revealed the necessity of examining the optimum $\mathrm{K}$ application, related specially to the effects of $\mathrm{N}: \mathrm{K}$ ratio (Chrysargyris et al., 2016). Therefore, $\mathrm{K}$ levels at this study were required to be kept in quite narrow levels, in order to meet the appropriate $\mathrm{N}: \mathrm{K}$ ratio. Potassium levels usually ranged of 300-350 $\mathrm{mg} \mathrm{L}^{-1}$ and more rarely above $400 \mathrm{mg} \mathrm{L}^{-1}$ based on nutritional demands of the crops (Savvas and Passam, 2002). Potassium shortage during plant growth leads to a decrease in chlorophyll content and photosynthetic rate (Gerardeaux et al., 2010), enzymes activation, poor growth and reduced yield (Kanai et al., 2007). The results of this study showed that $\mathrm{K}$ had no pronounced effect on most plant growth related parameters (except of leaf length) while considerable effects were observed in root development (root length and fresh weight) for the $325 \mathrm{mg}$ $\mathrm{L}^{-1} \mathrm{~K}$ application, and as such represented the most favorable treatment for its growth and development.
Leaf length increased possible due to the appropriate sugar signaling as suggested by Gerardeaux et al. (2010), however, a more precise examination is necessary before drawing definitive conclusions. In cotton and peanuts, Xiao-Li et al. (2008) and Almeida et al. (2015) indicated that $\mathrm{K}^{+}$accumulation was positively correlated with both root length and root surface area, increasing biomass and grain yields, respectively. In general, an improved root biomass would also lead to enhanced shoot biomass, however this trend was not clearly evidenced in the present study possibly due to the short period of plant development or to the narrow ranged $\mathrm{K}$ concentrations $\left(275-375 \mathrm{mg} \mathrm{L}^{-1} \mathrm{~K}\right.$ ) that were examined in order to prevent any $\mathrm{K}$ shortage during crop cultivation.

The content of chlorophylls, the chloroplast ultrastructure and the stomatal conductance are the main factors in the leaf photosynthetic rate (Zhao et al., 2001). In the present study, the content of chlorophylls (Chl a, $\mathrm{Chl} \mathrm{b}$ and total $\mathrm{Chl}$ ) and the stomatal conductance were not affected by the $\mathrm{K}$ levels, which definitely is not a negative issue, as it is implying similar photosynthetic rates among the examined $\mathrm{K}$ levels. The negative impact of $\mathrm{K}^{+}$deficiency on photosynthesis, transpiration and stomatal conductance is well documented (Kanai et al., 2007). Similar photosynthetic rates in the present study may be attributed to the fact that nitrogen concentration was $200 \mathrm{mg} \mathrm{L}^{-1}$ into the nutrient solution whereas, different $\mathrm{K}$ application affected the nitrogen:potassium ratio ranging from $1: 1.4(\mathrm{~N}: \mathrm{K})$ at $275 \mathrm{mg} \mathrm{L}^{-1} \mathrm{~K}$ up to 1:1.8 (N:K) at $375 \mathrm{mg} \mathrm{L}^{-1} \mathrm{~K}$. Savvas and Passam (2002) reported that the appropriate $\mathrm{N}: \mathrm{K}$ ratio for several vegetable and flower crops should vary among 1.5-2.2 and actually include the $300,325,350$ and $375 \mathrm{mg} \mathrm{L}^{-1}$ applications. K-shortage symptoms may not necessarily be readily visible or observed in the field due to a rapid reallocation of $\mathrm{K}$ within the plant, the fundamental importance of K may not be directly appreciated (Ren et al., 2013). 
Middle ranged potassium concentrations (300-350 mg $\mathrm{L}^{-1} \mathrm{~K}$ ) affected the antioxidative activity of the lavender plants. Consumers and market/industry require plant material with high antioxidant capacity, providing added value products. Inappropriate $\mathrm{K}$ levels may also induce stress responses (Cakmak, 2005) and as a consequence stresses can result in the accumulation of reactive oxygen species (ROS). The accumulation of ROS should be avoided as it may result in cell death due to several oxidative processes such as lipid peroxidation, protein oxidation and DNA damage (Gill and Tuteja, 2010). Plants scavenge ROS by increasing the antioxidant enzymes activities/contents, such as SOD, APX, CAT and glutathione reductase (GR) (Foyer and Noctor, 2011). $\mathrm{H}_{2} \mathrm{O}_{2}$ can be removed through the ascorbate-glutathione cycle AsA-GSH whereas the APX and the SOD are the key enzymes in this cycle (Pasternak et al., 2005). Antioxidant enzymes (SOD, CAT, peroxidase) activity increased in K-deficient bean leaves (Cakmak, 2005) and Houttuynia cordata (Xu et al., 2011). Results of the present study showed that $325 \mathrm{mg} \mathrm{L}^{-1}$ of $\mathrm{K}$ application decreased the MDA content compared with the $275 \mathrm{mg} \mathrm{L}^{-1}$ of $\mathrm{K}$, maybe by elimination of free radicals (Sharma et al., 2012). MDA increases with environmental stresses and is used for determination of lipid peroxidation or plasmalemma and organelle membranes damage evaluation (Wang et al., 2013). In general, oxidative stress was not evidenced in the present study as neither $\mathrm{H}_{2} \mathrm{O}_{2}$ production nor the activities of SOD, CAT and APX enzymes got significantly affected by $\mathrm{K}$ concentration. Shin et al. (2005) demonstrated that $\mathrm{H}_{2} \mathrm{O}_{2}$ is implicated (accumulated) in the regulation of plant response to $\mathrm{K}+$ starvation, which was not the case in the present study, as $\mathrm{K}+$ starvation was not evidenced, due to the well-balanced nutrient solution on $\mathrm{K}$ levels and $\mathrm{K}: \mathrm{N}$ ratio indeed.

Increasing $\mathrm{K}$ concentration affected macronutrients and micronutrient of both leaves and roots. In general, lower (i.e. $275 \mathrm{mg} \mathrm{L}^{-1} \mathrm{~K}$ ) levels into nutrient solution affected mainly micronutrients such as $\mathrm{Fe}, \mathrm{Zn}, \mathrm{Al}$ and B content, medium ( $325 \mathrm{mg} \mathrm{L}^{-1} \mathrm{~K}$ ) level affected $\mathrm{Ca}$, $\mathrm{Mg}, \mathrm{P}$ and $\mathrm{Mn}$ content while higher $\left(375 \mathrm{mg} \mathrm{L}^{-1} \mathrm{~K}\right.$ ) potassium level affected more the $\mathrm{N}$ and $\mathrm{K}$ content. In roots, the application of $325 \mathrm{mg} \mathrm{L}^{-1} \mathrm{~K}$ increased the content of $\mathrm{N}, \mathrm{K}, \mathrm{Mg}$, Na, and $\mathrm{B}$, while the $350 \mathrm{mg} \mathrm{L}^{-1}$ of potassium was mainly affected the Mn content in the roots. Potassium application may resulted in increased $\mathrm{N}$ level which actually depressed the $\mathrm{Ca}$ and $\mathrm{Mg}$ content, due to cation antagonisms (interactive effect), in $375 \mathrm{mg} \mathrm{L}^{-1} \mathrm{~K}$ treatments, and this was also found in wheat shoots but not in roots, although $\mathrm{K}$ did not affect the rate of Mg influx (Hafsi et al., 2014). Although the increased $\mathrm{K}$ levels resulted in higher contents of leaf potassium as compared to lower K levels, the higher leaf potassium did not improve the plant biomass, being in accordance with previous studies (Xu et al., 2011). Potassium interacts with almost all essential elements. A synergistic role of $\mathrm{K}$ with either $\mathrm{N}$ or P has been already noted (Nurzynska-Wierdak, 2013; Cecílio Filho et al., 2015).

Although the $375 \mathrm{mg} \mathrm{L}^{-1}$ of $\mathrm{K}$ application resulted in higher contents of potassium content in leaves but not in roots as compared to the $325 \mathrm{mg} \mathrm{L}^{-1}$, there were no any benefits on plant growth/development and essential oil yield. Enhancement in rate of metabolic processes with higher dose of $\mathrm{K}$ may also result in increased demand and utilization of other plant nutrients such as $\mathrm{N}$ and/or $\mathrm{P}$, being of prime importance. Thus, mineral overdoses may not only result in no plant growth benefits but also negatively affected environmental issues and human health. On the other hand, $\mathrm{K}$ deficiency inhibits nitrogen assimilation (Hafsi et al., 2014).

Essential oil yield and constituents in aromatic plants may be supported beneficially by the appropriate fertigation program during crop cultivation. Increasing the potassium rate (i.e. K:N) significantly differentiated 
the proportions of the particular components in the investigated lavender oils. In the present study, essential oil yield was increased in $300 \mathrm{mg} \mathrm{L}^{-1}$ of $\mathrm{K}$ application, while potassium:nitrogen rate affected the basil oil yield (Nurzynska-Wierdak, 2013). Similarly to our findings, the high $\mathrm{K}$ level decreased the essential oil content of bracts and leaves of Origanum dictamnus L. plants (Economakis, 1993). It has been reported in L. officinalis that 1,8-cineole, borneol and camphor were the predominant components of leaf volatile oil while 1.8-cineole, borneol, linalool and camphor were the major component of inflorescence oil (Chrysargyris et al., 2016). Essential oil quality decreases with increasing of camphor ratios (Biswas et al., 2009), consisting the 275,300 and $375 \mathrm{mg} \mathrm{L}^{-1} \mathrm{~K}$ treatment as the most appropriate one. Borneol is easily oxidized to the camphor (ketone) and this was evidence for the 325 and $350 \mathrm{mg} \mathrm{L}^{-1} \mathrm{~K}$ application. Moreover, the application of $300 \mathrm{mg} \mathrm{L}^{-1}$ of $\mathrm{K}$ resulted in increased 1.8-cineole and borneol content. The 1,8-cineole, also known as eucalyptol, due to the pleasant spicy aroma and taste is used extensively in cosmetics, fragrances and flavorings as well as it is used as an insecticide and insect repellent (Sfara et al., 2009).

In plants, the plastidial formation of monoterpenes $\left(\mathrm{C}_{10}\right)$ are synthesized from the plastid-derived geranyl diphosphate (GDP), and diterpenes $\left(\mathrm{C}_{20}\right)$ are synthesized from geranyl-geranyl diphosphate. In contrast, the cytoplasmic formation of sesquiterpenes $\left(\mathrm{C}_{15}\right)$ is synthesized from farnesyl diphosphate (FDP). Based on our findings, monoterpenes were predominated compared with the sesquiterpenes, indicating the 1-deoxy-D-xylulose-5-phosphate (DXP) pathway activation which is localized in plastids, compared with the classical mevalonic acid (MVA) pathway - operates in the cytocol and produces precursor for the biosynthesis of sesquiterpenes (which were in low percentages in the present study) and triterpenes, being in accordance with previous findings in lavender (Lane et al., 2010).
It is worthwhile to mention that several aromatic species, including species by Lamiacea family, are being harvested typically before or during the flowering period, before seed set, resulting in low regeneration and continues population drop. This fact increases the needs for species cultivation to ensure their conservation under sustainable usage strategy. Indeed, wild medicinal species cultivation is not so simple, as it requires a good interpretation to their adaptation in different microclimate and/or cultivation practices with direct impacts on their chemical composition and/or bioactivity. Successful cultivation and marketing of medicinal and aromatic plants requires reproducibility of bioactive compounds, and on that task, medicinal plants cultivated in hydroponics provide stable and controlled-manner bioactivity. Suitable cultivation practices are needed while controlled mineral uptake either in soils or through hydroponics is one effective way for favorable plant growth and appropriate EO biosynthesis.

\section{Conclusions}

We examined the effects of potassium rates on hydroponically grown lavender plants, under controlled nutrition status and the middle $\mathrm{K}$ levels 300$350 \mathrm{mg} \mathrm{L}^{-1}$ benefited antioxidant activity of lavender. Considering greater essential oil yield and lower camphor percentage, the $300 \mathrm{mg} \mathrm{L}^{-1} \mathrm{~K}_{\text {treatment }}$ could be appropriate for lavender cultivation and production for essential oil uses. Indeed, considering the content for $\mathrm{Ca}, \mathrm{P}, \mathrm{Mg}$ and $\mathrm{Mn}$, lower $\mathrm{Al}$ content, the $325 \mathrm{mg} \mathrm{L}^{-1} \mathrm{~K}$ treatment could be appropriate for lavender cultivation and production for fresh and dry matter uses.

Careful nutrient management is essential to balance high growth in biomass with the production of high quality oil - two essential parameters for profitable production, environmental and human safe. 


\section{Acknowledgements}

This work has been financed by the Start-up grant for the research project SALTAROMA in Cyprus University of Technology.

\section{References}

Almeida, H.J., Pancelli, M.A., Prado, R.M., Cavalcante, V.S., Cruz, F.J.R. 2015. Effect of potassium on nutritional status and productivity of peanuts in succession with sugarcane. J. Soil Sci. Plant Nutr. 15(1), 1-10.

Azevedo-Neto, A.D., Prisco, J.T., Enéas-Filho, J., Abreu, C.E.B., Gomes-Filho, E. 2006. Effect of salt stress on antioxidative enzymes and lipid peroxidation in leaves and roots of salt-tolerant and salt sensitive maize genotypes. J. Environ. Exp. Bot. 56, 87-94.

Biesiada, A., Sokol-Letowska, A., Kucharska, A. 2008. The effect of nitrogen fertilization on yielding and antioxidant activity of lavender (Lavandula angustifolia Mill.). Acta Sci. Pol. 7, 33-40.

Biswas, K.K., Foster, A.J., Aung, T., Mahmoud, S.S. 2009. Essential oil production: relationship with abundance of glandular trichomes in aerial surface of plants. Acta Physiol. Plant. 31, 13-19.

Cakmak, I. 2005. The role of potassium in alleviating detrimental effects of abiotic stress in plants. J. Plant Nutr. Soil Sci. 168, 521-530.

Cecílio Filho, L.A.B., Feltrim, A.L., Mendoza Cortez, J.W., Gonsalves, M.V., Pavani, L.C., Barbosa, J.C. 2015. Nitrogen and potassium application by fertigation at different watermelon planting densities. J. Soil Sci. Plant Nutr. 15 (4), 928-937.

Chrysargyris, A., Panayiotou, C., Tzortzakis, N. 2016. Nitrogen and phosphorus levels affected plant growth, essential oil composition and antioxidant status of lavender plant (Lavandula angustifolia Mill.). Ind. Crops Prod. 83, 577-586.

Economakis, C.D. 1993. Effect of potassium on growth and yield of Origanum dictamnus in growth culture. Acta Hort. 331, 339-344.

Foyer, C.H., Noctor, G. 2011. Ascorbate and glutathione: the heart of the redox hub. Plant Physiol. 155, 2-18.

Gerardeaux, E., Jordan-Meille, L., Constantin, J., Pellerin, S., Dingkuhn, M. 2010. Changes in plant morphology and dry matter partitioning caused by potassium deficiency in Gossypium hirsutum (L). Environ. Exp. Bot. 67, 451-459.

Gill, S.S., Tuteja, N. 2010. Reactive oxygen species and antioxidant machinery in abiotic stress tolerance in crop plants. Plant Physiol. Biochem. 48, 909-930.

Hafsi, C., Debez, A., Abdelly, C. 2014. Potassium deficiency in plants: effects and signaling cascades. Acta Physiol. Plant. 36, 1055-1070.

Jiang, M., Zhang, J. 2002. Involvement of plasma membrane NADPH oxidase in abscisic acid- and water stress-induced antioxidant defense in leaves of maize seedlings. Planta. 215, 1022-1030.

Kanai, S., Ohkura, K., Adu-Gyamfi, J.J., Mohapatra, P.K., Nguyen, N.T., Saneoka, H., Fujita, K. 2007. Depression of sink activity precedes the inhibition of biomass production in tomato plants subjected to potassium deficiency stress. J. Exp. Bot. 58, 2917-2928.

Klados, E., Tzortzakis, N. 2014. Effects of substrate and salinity in hydroponically grown Cichorium spinosum. J. Soil Sci. Plant Nutr. 14, 211-222.

Lane, A., Boecklemann, A., Woronuk, G.N., Sarker, L., Mahmoud, S.S. 2010. A genomics resource for investigating regulation of essential oil production in Lavandula angustifolia. Planta. 231, 835-845. 
Loreto, F., Velikova, V. 2001. Isoprene produced by leaves protects the photosynthetic apparatus against ozone damage, quenches ozone products, and reduces lipid peroxidation of cellular membranes. Plant Physiol. 27, 1781-1787.

Miliauskas, G., Venskutonis, P.R., Van Beek, T. 2004. Screening of radical scavenging activity of some medicinal and aromatic plant extracts. Food Chem. 85, 231-237.

Nurzynska-Wierdak, R. 2013. Does mineral fertilization modify essential oil content and chemical composition in medicinal plants? Acta Sci. Pol.Hortoru. 12, 3-16.

Page, M.J., Di Cera, E. 2006. Role of $\mathrm{Na}+$ and K+ in enzyme function. Physiol. Rev. 86, 1049-1092.

Pasternak, T., Rudas, V., Potters, G., Jansen, M.A.K. 2005. Morphogenic effects of abiotic stress: Reorientation of growth in Arabidopsis thaliana seedlings. Environ. Exp. Bot. 53, 299-314.

Puttanna, K., Rao, E.V.S.P., Singh, R., Ramesh, S. 2010. Influence of nitrogen and potassium fertilization on yield and quality of rosemary in relation to harvest number. Commun. Soil Sci. Plant Anal. 41, 190-198.

Ren, T., Lu, J., Li, H., Zou, J., Xu, H., Liu, X., Li, X. 2013. Potassium-fertilizer management in winter oilseed-rape production in China. J. Plant Nutr. Soil Sci. 176, 429-440.

Richardson, A.D., Duigan, S.P., Berlyn, G.P. 2002. An evaluation of noninvasive methods to estimate chlorophyll content. New Phytol. 153, 185-194.

Savvas, D., Passam, H. 2002. Hydroponic production of vegetables and ornamentals. Embryo Publications, Athens, Greece. 2002, pp. 462.

Sfara, V., Zerba, E.N., Alzogaray, R.A. 2009. Fumigant insecticidal activity and repellent effect of five essential oils and seven monoterpenes on first-instar nymphs of Rhodnius prolixus. J. Med. Entomol. 46, 511-515.
Sharma, P., Jha, A.B., Dubey, R.S., Pessarakli, M. 2012. Reactive oxygen species, oxidative damage, and antioxidative defense mechanism in plants under stressful conditions. J. Bot. Article ID 217037,26 p.

Shin, R., Berg, R.H., Schachtman, D.P. 2005. Reactive oxygen species and root hairs in Arabidopsis response to nitrogen deprivation. Proc. Natl. Acad. Sci. USA 101, 8827-8832.

Tzortzakis, N., Borland, A., Singleton, I., Barnes, J. 2007. Impact of atmospheric ozone-enrichment on quality-related attributes of tomato fruit. Postharvest Biol. Technol. 45, 317-325.

Wang, M., Zheng, Q., Shen, Q., Guo, S. 2013. The critical role of potassium in plant stress response. Int. J. Mol. Sci. 14, 7370-7390.

Xiao-Li, T., Gang-Wei, W., Rui, Z., Pei-Zhu, Y., LiuSheng, D., Zhao-Hu, L. 2008. Conditions and indicators for screening cotton (Gossypium hirsutum L.) varieties tolerant to low potassium. Acta Agric. Sinica. 34, 1435-1443.

Xu, Y.W., Zou, Y.T., Husaini, A.M., Zeng, W.J., Guan, L.L., Liu, Q., Wu, W. 2011. Optimization of potassium for proper growth and physiological response of Houttuynia cordata Thunb. Environ. Exp. Bot. 71, 292-297.

Yadegari, M. 2015. Foliar application of micronutrients on essential oils of borago, thyme and marigold. J. Soil Sci. Plant Nutr. 15(4), 949-964.

Zhao, D., Oosterhuis, D.M., Bednarz, C.W. 2001. Influence of potassium deficiency on photosynthesis, chlorophyll content, and chloroplast ultrastructure of cotton plants. Photosynthetica. 39, 103-109.

Zhu, Z., Wei, G., Li, L., Qian, Q., Yu, J. 2004. Silicon alleviates salt stresses and increases antioxidant enzymes activity in leaves of salt-stressed cucumber (Cucumis sativa L.). Plant Sci. 167, 527-533. 